IRYNA KURLAK

Wydział Nauk Pedagogicznych

Uniwersytet Kardynała Stefana Wyszyńskiego w Warszawie

ORICID ID: http://orcid.org/oooo-ooo2-1551-3699
Forum Pedagogiczne $9(2019) 1$

Wpłynęło: 03.02.2019

Zatwierdzono do druku: 24.04.2019 DOI: 10.21697/fp.2019.1.18

\title{
SEXUAL ADDICTION: TERMINOLOGY, ETIOLOGY, PHENOMENOLOGY AND DIAGNOSTICS
}

\begin{abstract}
This article analyzes selected aspects of the construct of sexual addiction as a manifestation of behavioral addiction on the basis of an interdisciplinary approach. It emphasizes the role of sensuality and selectivity of a healthy person in the sexual life. The emphasis is put on defining problems of sexual addiction and the identification of its specific, characteristic features that distinguish it from other similar concept. Historical and diagnostic aspects of the study of the construct of erotomania are also described. The article analyzes various triggers that may affect the onset of sexual addiction: somatic, mental, social, situational.
\end{abstract}

Keywords: sex; addiction; sexual addiction; erotomania; causes; diagnosis.

\section{Introduction}

Among the numerous well-known behavioral addictions, sexual addiction occupies a special place. This type of disorder evokes rising interest of many scientists, not only psychologists, psychiatrists, sexologists, but also specialists of other disciplines, in particular teachers and social workers, who either are directly in contact with manifestations of dysfunctional behavior of people with such deviations or provide assistance to their families. These specialists are interested in sexual addiction for several reasons. Firstly, it is associated with numerous negative consequences for the psychosocial functioning of affected people as well as for members of their families who often become co-addicted. Secondly, the rapid development of advanced communication technologies of the $21^{\text {st }}$ century create unprecedented favorable conditions for this type of addiction. Internet is particularly blamed for the widespread of pornography, cybersex, pedophilia, and other pathological forms of satisfying sexual desires. Thirdly, due to the rapid development of the global network, extremely young teenagers and even children who overuse the internet increase their interest in eroticism and sex, which subsequently together with 
the lack of parental control, can lead to their demoralization and addiction. Finally, addiction to sex does not have such expressive external physical manifestations as alcoholism or drug addiction, and as a result it can remain unnoticed for a long time.

\section{Issues with terminology and definitions}

Professional literature provides various terms that describe excessively intense sexual behavior, proving the complexity and ambiguity of the analyzed construct: "Casanova”, "Don Juan", "Messalina Complex", pathologically high number of partnerships, pathological sexuality, sexual or compulsive promiscuity, erotomania, urethromania, hyper eroticism, hyperlibidemia, hypersexuality (excessive sexuality, pansexualism), compulsive sexual behavior, hypersensuality, libertinism (Guerreschi, 2012, p. 46); nymphomania (for women) and satyriasis (for men) (Lew-Starowicz, 1985a, p. 231), sexual obsession, persistent genital arousal disorder, love addiction, moral insanity, hedonism (Levine, 2010, p. 262), cybersex or sex internet activity, SIA (for the internet-triggered sexual behavior) (Zwoliński, 2014, p. 102).

"Sexual addiction" is the most frequent term used in the Polish professional literature. The authors in American publications describe the issue as sexual addiction, compulsive sexual behavior, sexual compulsivity or hypersexuality (Hook et al., 2010, p. 229). Sexual addiction and sexual compulsivity are two prevailing models. The proponents of the addiction model indicate clinical similiarities between the criteria for the sexual addiction and for DSM-IVR substance addiction. Those in favor of the compulsivity model claim that the deviant sexual behavior is related to the basic obsessive-compulsive disorder where sexual activities soothe the agitation. Compulsivity is explained as a kind of behavior driven by an attempt to avoid aversive internal tension (Goodman, 1992, p. 303).

Other than the two models discussed above there is a third model known as deregulated sexual desires (Kafka, 2010a, p. 281) defined as a human appetitive behavior such as night dreams, appetite, desire and sex that can become deregulated or disinhibited (Kafka, 2010b, p. 394).

It is a daunting task to define the issue of sexual addiction. A serious evidencebased discussion has been going on in the American literature. The key features of addictive behavior proposed by Goodman (1992, p. 305) are a repeated failure of sexual behavior control and continuation of unwanted behavior despite detrimental consequences. In the theoretical model developed by the same author, three components can be distinguished: disturbed regulation of influence, disturbed behavioral inhibition and improper operation of the incentive reward system (Bancroft \& Vukadinovic, 2004, p. 231).

In 1991, Patrick Carnes introduced the first complete definition of sexual addiction. "Sexual addiction is an unsound attitude to sex aimed at a reduction 
of the feeling of stress to escape from negative or painful emotions and from intimate relationships that a person cannot cope with. Sexual relationship becomes a fundamental need, for which all the rest is sacrificed, while other people are considered to be objects for utility purposes." (translated by the author; in Guerreschi, 2012, p. 45) In a similar way Tonino Cantelmi et al. (2004) define this concept, while emphasizing that for a sex addicted individual various expressions of sexual behavior are part of their thoughts, feelings and actions that remain beyond his or her control. Russell Willingham (2014, p. 31) focuses on another aspect, pointing out that sexual addiction is an obsessive-compulsive disorder. Its manifestation is contingent upon a person, subject, or experience through which a sexual pleasure can be obtained. Zbigniew Lew-Starowicz (1999, p. 83-84) defines sexual addiction (erotomania) as a disorder characterized by an increase in erotic interest and sexual activity, in which sexual need dominates over other needs. This entails a frequent change of partners, a tendency to participate in orgies, a very high frequency of sexual intercourses with a simultaneous sensation of sexual discontentment. In erotomania, a person is enslaved by sex, which becomes the basic motive of their actions (Lew-Starowicz, 1985b, p. 313). Arthur S. Rebera and Emily S. Reber (2008, p. 211) claim that erotomania is characterized by general excessive sexual desire.

Hook et al. (2010, p. 229) proposed their own definition of sexual addiction. A person addicted to sex is someone experiencing persistent, intense sexual arousal, fantasy, libido or behavior that (a) cannot be controlled and that (b) causes significant suffering. This definition highlights the negative consequences of this phenomenon. S. B. Levine (2010, p. 264) emphasizes that sexual addiction is a chronic, recurrent disorder in which habitual sexual stimulation persists despite serious negative consequences.

The definition of another related term, hypersexuality, also highlights a lack of relationship between sexual partners: "Hypersexuality is a group of disorders manifested by the loss of control over the amount of feelings based on fantasies. One of the features of hypersexuality is the loss of control over sexual behavior that performs a dominant function in a patient's life as a mood regulator rather than a creator of close relationships." (Muldner-Nieckowski, 2015, p. 19) Thus, sex for erotomaniacs is only an illusion of true love and proximity (Smaś-Muszczyszyn, 2014, p. 45). In these circumstances, there is no place for love or a sensual intimacy with a partner because the agitated sexual desires demand new and ever more powerful stimuli (Bębas, 2013, p. 45).

Paula Hall wrote (2014, p. 38; translated by the author): "Sexual addiction is not about defusing a sexual tension. The addicts do not crave for orgasm, as much as they want to escape from life."

Term "promiscuity" is also ambiguous in professional literature. It is considered by some as synonymous with sexual addiction. It means frequent changes of sexual partners in non-emotional contacts, as well as a significant number of sexual 
intercourses. However, such individuals feel themselves, most often, entirely normal and healthy, and because of this do not see the need for professional assistance, but, conversely, even have a feeling of superiority over others. In the diagnosis of promiscuity, the most important criterion is the number of sexual partners. The real number is a problem, because very few keep an accurate account of sexual partners. Studies show that some such individuals during the lifetime have the number of sexual partners that ranges from 500 to 1000 , but the vast majority of people with diagnosed promiscuity have had from 100 to 200 partners. If you compare this data with the number of sexual partners in a typical population, then there is a striking difference. Most women have in their lives 1-5 partners, and men 2-10 partners (Lew-Starowicz, 1988a, p. 108). One of possible explanations for the situation can be according to Buss $(1996$, p. 112) the fact that women involve themselves into new extramarital relations when they are not satisfied with previous one. In case of men there is no correlation between a happy marriage and adultery.

\section{Diagnostic aspects of the sexual addiction}

For the first time, the hypothesis of the existence of addiction to sex appeared at the end of the 19th century, when Richard Krafft-Ebing argued that sex could become so intense an activity that it would affect all other aspects of human life (Guerreschi, 2012, p. 45). He added that pathological sexuality can become a threat to the life of the individual, since it puts them in a situation of violation of both state and moral laws, up to the loss of dignity, freedom and life. According to him pathological sexual behavior should be regarded as a mental illness. Almost 100 years later, Jim Orford argued that "oversexuality" ("hypersexuality") should be included in the range of addiction-related disorders (Dąbkowska, 2014, p. 164).

Sexual addiction is currently considered a growing problem, hence the ample body of research in this area. This is evidenced by 773 articles published in the American scientific journals as of January 2009 (Hook et al., 2010, p. 229).

In publications related to hypersexuality, particular attention is drawn to the problems of assessment. This is connected, firstly, with the fact that the outline of the normal power of sexual desire is a conditional affair. It depends on the customary rules prevailing in this environment, as well as on the all-inone image of an individual and the effectiveness of his or her social functioning (Imieliński, 1986, p. 175). Secondly, most people who have a lot of love affairs and are sexually abusive show no signs of sexual addiction (Rosenberg et al., 2014, p. 79). Because of this, it is crucial to construct a special assessment tool that would clearly distinguish the intense sexual life from addiction.

Another interesting issue related to the assessment of sexual addiction is an attempt to outline at least an approximate number of people who are addicted to sex in the population. Such attempts have been made in the U.S. where Alfred Kinsey has determined that signs of hypersexuality are shown by men who reach more than seven orgasms a week. On this basis, hypersexuality was diagnosed in 
7.6\% of the American male population (Rosenberg et al., 2014, p. 78). The percentage of sex addicts in the USA ranges from $5 \%$ to $18 \%$ (Zapf et al., 2008, s. 159). Similar results were obtained in Italy. According to the Italian Institute of Psychotherapy Researches (Guerreschi, 2010, p. 160), 6\% of Italians in the age between 20 and 45 years show symptoms of addiction to sex.

Patrick Carnes (2001, p. 18) offered 10 diagnostic criteria for sexual addiction: 1) loss of control over sexual behavior; 2) tangible negative consequences of that sexual behavior; 3) inability to stop such behavior; 4) return to auto-destructive behavior and very risky situations; 5) stubborn efforts and desire to stop dependent behavior; 6) sex-centeredness and fantasies as the main strategy for solving problems in life; 7) an increasing number of sexual contacts and experiences; 8) profound changes in habituation; 9) spending time on persistent thoughts connected with searching for opportunities for sex, engaging in it and overcoming consequences; 10) the neglect of professional, personal affairs and rest. The reason to perceive the sexual addiction as an addiction is the diagnostic criteria formulated by A. Goodman (1992). He suggested that, based on DSM-IV substance abuse criteria, we should establish similar symptoms for sexual addiction. So, among the criteria were tolerance and some other syndromes (Zdrada, 2017, p. 62).

M.P. Kafka (2010a, p. 379) presented an assessment model for hypersexual disorder. It introduced such an important criterion as subjective suffering of the individual and social role dysfunction (Dąbkowska, 2014, p. 168). According to M. Kafka's criteria (2010b, p. 281), hypersexuality is diagnosed when recurrent and intense sexual fantasies, desires and behaviors occur over a period of at least 6 months. There are clinically significant anxiety and disorders in other important areas of functioning related to the frequency and intensity of these fantasies, desires and behaviors. There are also serious negative consequences including severe dysfunction of the partner bond, marriage problems, divorce, sexually transmitted diseases (e.g. HIV), significant expenses, a loss of job and unwanted pregnancies.

Practical challenges for the assessment of sexual addiction came from the massive use of the internet for sexual practices. The results of the research entitled "Sexuality of Poles between 2011 and 2017" showed that in Poland 86\% of internet-users regularly visit pornographic web pages; the average age of children who first encounter pornographic material on the Internet is 11 years old; $31 \%$ of internet-users had sex in real life with people they met on the Internet (LewStarowicz, 2018, p. 34).

The appropriate criteria for the diagnosis of SIA were also developed. In 2001 Mark Griffiths proposed 6 criteria for diagnosing SIA, and, in addition to the phenomenon of toleration and other syndromes, mentioned above, included: importance (the dominance of SIA over other forms of human activity), mood change, as well as conflict (social and psychological problems) and relapses (Pozdal, 2008, p. 128). Paula Hall (2014, p. 41) has also proposed her diagnostic system. In addition to traditional questions, it included issues related to the presence 
of other types of addictions in the diagnosed person and her parents, which is evidence of the complex nature of addictive behavior. Research by Rosenberg et al. (2014, p. 79) confirms that people addicted to sex become also addicted to alcohol, cigarettes, drugs, compulsive overeating, or gambling.

Marta Kołacka (2014, p. 45) believes that sexual addiction can be diagnosed on the basis of six signs. These include: a sense of coercion; lack of control over behavior; the need for stronger impressions (tolerance); abandonment of obligations; restriction of other pleasures; continuation of the activity, despite its harmfulness. Along with the development of research on sexual addiction, diagnostic tools for measuring this issue have also been devised. Hook et al. (2010, p. 229) have thoroughly analyzed 17 tools. They combined three types of information: objective symptoms of sexual addiction, subjective symptoms and consequences of sexual addiction.

\section{Behavioral types of erotomaniacs}

Empirical studies by Patrick Carnes (2001, p. 50-53) have shown that erotomaniacs possess a much bigger slew of sexual behavioral forms, use them more often and consider them to be effective. In reality these forms of behavior show powerlessness of addicted people since they illustrate the impossibility of rejecting the destructive activity. P. Carnes (2001, p. 54-55) distinguishes 11 behavioral types of sexual addiction: (1) Fantasizing. Examples of behavior: having long hours of sex dreams and future contacts or reproducing images from the past; neglecting responsibilities; creation of erotic atmosphere. (2) Temptation. Dragging yourself into a few erotic contacts at one time or one by one; flirting; reviewing proposals of a matrimonial office; touching others in bars, discos; avoiding permanent duties to support sexual willingness; conducting conversations on sexual topics. (3) Anonymous sex. Sexual relationships with anonymous partners; roaming along the beaches, parks, public toilets and baths in order to find a partner, rubbing against people in the crowd; participation in group orgies. (4) Paid sex. Paying for obscene telephone conversations; visits to erotic massage rooms, striptease clubs, use of services of sexual agencies; keeping mistresses or lovers. (5) Sex for money. Participation in production of pornographic materials; posing and sex work for photos and films; prostitution and pimping; taking money or drugs for performing the functions of a mistress (lovers). (6) Peeping or voyeurism (from French voir, which means 'watch', is observing the shelter of other people during undressing or sex game). Use of pornographic materials; visits to sex shops, cabins video, beach nudists, striptease clubs, porn cinemas, the use of optical devices for catching people in sexual situations. (7) Exhibitionism. Undressing in public spaces (parks, streets, sports grounds); stripping off in open windows, on balconies, on roofs or in cars; sexual practices in public places. (8) Imposing sex. Tireless sexual harassment (including alcohol or drug use or use of their position), touching and groping others 
without their consent; telling vulgar stories or anecdotes, using vulgar language. (9) Sadomasochism. Harming himself or herself during sexual contact or causing pain to himself or herself to enhance the effect of sexual stimuli; playing the role of a victim in sexual contact; the use of accessories for torture. (10) Sex with objects. Masturbation using items, accessories and dolls, changing clothes, using fetishes for sexual rituals, sexual relations with the dead (necrophilia) and animals (zoophilia). (11) Pedophilia and incest. Retelling children obscene sexual information, sexual harassment towards children, showing them adult sexual contacts, coercion of children for sexual practices, child prostitution and pornography.

In 2010 Kaplan and Krueger (2010, p. 182-183) listed 6 types of hypersexual behavior: masturbation, pornography, sexual behaviors with consensual adults, cybersex, phone sex and strip clubs. A sex addict tends to „specialize” in one or more types of sexual behavior, similarly to a drug addict who will stick to one or several substances (Goodman, 1992, p. 309).

The forms of sexual behavior are different in different groups of people. First of all, it depends on gender. Men often use paid or anonymous sex and more often use compulsive masturbation and behavior that has the nature of paraphilia (perversion). Unlike women who tend to be more flirting and addicted to love. Sexual addiction manifests differently in specific populations. Significantly higher rate of distribution of this problem is among sexual offenders. Per Liam E. Marshall et al's research (2008), 35-43\% of investigated sexual offenders were addicted to sex (as compared with $12-15 \%$ in the control group).

\section{Causes of sexual addiction}

The notion of sexual addiction is rooted in different theories and concepts biological, psychological, sociological, cultural (Woźniak, 2012, p. 11-32). The international literature is dominated by biopsychological explanations related to attachment processes, "super-charged erotic urges" or multimodal theories (Zapf et al., 2008, p. 159).

People are different in many aspects, including ability to suppress their sexual behavior. In some people, the tendency to oppress sexual desire does not appear at all, which may lead to sexual addiction (Penix Sbraga \& O'Donohue, 2003, p. 10). The second factor is the effect of a reduced mood on a human sexuality. Most people who suffer from depression or fear decrease their interest in sex. However, there are those who have the opposite tendency, that is, their sexual behavior helps them to feel better in difficult situations. Sexual contact allows them to satisfy their emotional needs in a state of depression, making personal contact through sex, which strengthens their self-esteem (Bancroft \& Vukadinovic, 2004, p. 230).

Paula Hall (2014, p. 39) has established three key sources of sexual addiction, 1) favorable circumstances; 2) traumatic experience; 3) attachment disorders. She adds mental and other disorders to the list. 
As for the first one, it should be emphasized that people still have never had such opportunities to be addicted to sex as in the era of the Internet. Addiction to sex in cyberspace is manifested by the persistent browsing the web-pages with pornographic texts, pictures, photos, films, erotic games, as well as the setting up erotic contacts on the Internet and being involved in cybersex (Nowosielski, 2010, p. 289). Also popular are chat-rooms - virtual places for sharing opinions and views on sex (Rowicka, 2015, p. 41).

It can be safely stated that the situation is aggravated by ineffective education (Hall, 2014, p. 40). The syllabus for a class known as "Family Life Education" has been proven not to meet the students' expectations. As research showed, most young people said that even when such classes were offered, they were usually uninteresting (Zabielska, 2009, p. 83). Jaczewski (2014, p. 180) confirms incompetence among the teachers. Jacek Kurzępa (2008, p. 221-222) concludes that school children are fully aware of erotic and sexual behaviors. It was found that adolescent boys in particular perceive sex as a sport, and get engaged in bisexual, homoerotic and autoerotic practices. Girls at this age also crave for sex by displaying erotic needs, provocative behavior, and a search for sexual intercourse.

Family situation can also greatly impact the development of sexual addiction. In Patrick Carnes' studies (2001), the majority of both addicted (68\%) and co-addicted (63\%) people came from families where children did not experience warm feelings from their parents. A significant number of people from both groups experienced emotional violence ( $97 \%$ and $91 \%$ respectively), physical ( $72 \%$ and $81 \%$ ) and sexual ( $81 \%$ and $71 \%)$. Similarly single-parent environment is also conducive to triggering hypersexuality (Buss, 1996, p. 115).

Individuals who have experienced trauma as a result of sexual violence or rape, may become addicted to sex. One of the hypotheses says that a paradoxical relationship of mood and sexuality develops in childhood or early adolescence as a consequence of the experience of combining sexual reaction with the negative mood that occurred as a result of child sexual abuse or guilt associated with masturbation (Bancroft \& Vukadinovic, 2004, p. 227).

An important factor in the cause of sexoholism is the third factor, the attachment disorder. Zapf et al. (2008, p. 159) proved that men with sexual addictions have a love affair characterized by uncertain attachment with a strong presence of anxiety and avoidance. Such people lack intimate feeling, are insecure, are unable to rely on others, consider themselves unworthy of love and support and are more interested in emotionless sex.

If the attachment disorder develops in childhood, people can no longer build close relationships with other people in adult life. They do not trust others or use manipulative way of interacting with others (Hall, 2014, p. 39). Those who have not been in a close relationship from an early age will long for a relationship and fantasize about "metaphorical substitutes" (Zapf et al., 2008, p. 159). Coleman (1986) argued that the predisposition to pathological sexual behavior may arise in order 
to alleviate the emotional pain associated with "intimate dysfunction" that can cause sexual abuse or neglect of the child (see Bancroft \& Vukadinovic, 2004, p. 232).

Erotomania can be a symptom of different groups of disorders: a maniac or hypomaniac condition, schizophrenia or psychopathy (when it comes to damages of the process of mentally-sensory integral oppression which is showed through the intensity and shamelessness of sexual life). Organic diseases that can induce erotomania include organic changes in the brain, hormonal disorders, as well as drug abuse (cocaine, heroin, mescaline) and carbon monoxide poisoning (Imieliński, 1990a, p. 74). Sexual addiction can also be a result of brain cancer, some types of epilepsy or atherosclerotic lesions (Lew-Starowicz, 2014, p. 53). Hypersexual behavior is usually associated with dysphoric disorders such as anxiety, depressive mood, irritability and boredom. Taking risks and looking for sensations may be related to mood disorders as well as ADHD (Kafka, 2010a, p. 39o).

Erotomania can be caused also situationally. It appears in people who do not have the opportunity to satisfy their sexual needs because of the absence of partners of another gender (for example, prisoners, sailors). Forced sexual restraining in such cases sometimes causes excessive sexual arousal and leads to homosexuality (Imieliński, 199ob, p. 73).

\section{Conclusions}

Sexual addiction is one of very dangerous behavioral addictions that became the subject of serious scientific interest in different countries (especially in the U.S., Great Britain, France, German, Italy) as far back as $19^{\text {th }}$ century. And from those times we have intensive scientific researches of the notion but because of its complexity and ambiguity we still do not have a commonly accepted term for its adequate description (sexual addiction, erotomania, hypersexuality, promiscuity etc.). According to M. Kafka (2010b), there are three different perspectives for explaining the hypersexual disorder: the addiction model, the compulsivity model and the deregulation model of desire. Each model describes a persistent, more frequent and intense sexual behaviors that cannot be controlled and that cause clinically significant distress or disability due to serious negative consequences. This is a clear indication that the addiction to sex has a very destructive impact on an individual and their environment. The sexual addiction patient's intimate relationships, social support system and quality of life are at risk. It is this inability to control compulsive sexual life deprived of deeper feelings and replete with a sense of anxiety differentiates sexual addiction diagnosed as a disease from a search of intimacy and love. 


\section{References}

Bębas, S. (2013). Patologie społeczne w sieci. Toruń: Wydawnictwo „Akapit.

Buss, D.M. (1996). Ewolucja pożądania. Strategie doboru seksualnego ludzi. Gdańsk: Gdańskie Wydawnictwo Psychologiczne.

Bancroft, J., \& Vukadinovic, Z. (2004). Sexual Addiction, Sexual Compulsivity, Sexual Impulsivity, or What? Toward a Theoretical Model. The Journal of Sex Research, 41(3).

Cantelmi, T., Lambiase, E., \& Sessa, A. (2004). Le dipendenze comportamentali. Rivista Psicobiettivo, 24(2). Retrieved from http://www.toninocantelmi.it/index. php/la-mente-in-internet/le-dipendenze-comportamentali

Carnes, P. (2001). Od nałogu do miłości: Jak wyzwolić się z uzależnienia od seksu i odnaleźć prawdziwe uczucie. Poznań: Wydawnictwo „Media Rodzina”.

Dąbkowska, M. (2014). Zaburzenie hiperseksualne - aspekty historyczne, diagnostyczne i terapeutyczne. In K. Wasilewska-Ostrowska (Ed.). Praca socjalna z osoba uzależniona i jej rodzina. Wybrane problemy. Warszawa: Wydawnictwo „Difin”.

Giddens, A. (2006). Przemiany intymności. Seksualność, miłość i erotyzm we wspótczesnych społeczeństwach. Warszawa: Wydawnictwo Naukowe PWN.

Goodman, A. (1992). Sexual Addiction: Designation and Treatment. Journal of Sex \& Marital Therapy, 18(4).

Guerreschi, G. (2010). Nowe uzależnienia. Kraków: Wydawnictwo „Salwator”.

Guerreschi, G. (2012). Uzależnienie od seksu. Kiedy seks może zabić. Kraków: Wydawnictwo Franciszkanów „Nowy Zew”.

Hall, P. (2014). Nie orgazm lecz ucieczka. Charaktery. Magazyn Psychologiczny, 4. Hook, J.N., Hook, J.P., Davis, D.E., Worthington, E.L., \& Penberthy, J.K. (2010). Measuring Sexual Addiction and Compulsivity: A Critical Review of Instruments. Journal of Sex \& Marital Therapy, 36.

Jaczewski, A. (2014). Seksualność dzieci i młodzieży. Pół wieku badań i refleksji. Warszawa: Wydawnictwo Difin.

Imieliński, K. (1985). Człowiek i seks. Warszawa: Instytut Wydawniczy Związków Zawodowych.

Imieliński, K. (1986). Zarys seksuologii i seksiatrii. Warszawa: Państwowy Zakład Wydawnictw Lekarskich.

Imieliński, K. (1990a). Sekrety seksu. Warszawa: Instytut Wydawniczy Związków Zawodowych.

Imieliński, K. (199ob). Seksiatria. Patologia seksualna. Warszawa: Państwowe Wydawnictwo Naukowe.

Kafka, M. (2010a). Hypersexual Disorder: A Proposed Diagnosis for DSM-V. Archives of Sexual Behavior, 39.

Kafka, M. (2010b), Commentary "What is Sexual Addiction?" A Response to Stephen Levine. Journal of Sex \& Marital Therapy, 36.

Kołacka, M. (2014). Utajony problem. Charaktery. Magazyn Psychologiczny, 11. 
Kaplan, M., \& Krueger, R. (2010). Diagnosis, Assessment, and Treatment of Hypersexuality. Journal of Sex Research, 47(2-3).

Kurzępa, J. (2008). Zagrożona niewinność. Zakłócenia rozwoju seksualności współczesnej młodzieży. Kraków: Oficyna Wydawnicza Impuls.

Levine, S.B. (2010). What is Sexual Addiction? Journal of Sex \& Marital Therapy, 36.

Lew-Starowicz, Z. (1985a). Leczenie czynnościowych zaburzeń seksualnych. Warszawa: Państwowy Zakład Wydawnictw Lekarskich.

Lew-Starowicz, Z. (1985b). Seks dojrzały. Warszawa: Państwowy Zakład Wydawnictw Lekarskich.

Lew-Starowicz, Z. (1988a). O seksie, partnerstwie i obyczajach. Warszawa: Wydawnictwo Współczesne.

Lew-Starowicz, Z. (1988b). Seks nietypowy. Warszawa: Instytut Wydawniczy Związków Zawodowych.

Lew-Starowicz, Z. (1999). Słownik encyklopedyczny: Miłość i Seks. Warszawa: Wydawnictwo „Europa”.

Lew-Starowicz, Z. (2014). Pod wpływem demona seksu. Charaktery. Magazyn Psychologiczny, 5.

Lew-Starowicz, M. (2018). Kochanie czy klikanie. Terapia dla zagubionych kobiet i mężczyzn. Bielsko-Biała: Wydawnictwo „Pascal”.

Marshall, L.E., Marshall, W.L., Moulden, H.M., \& Serran, G.A. (2008). The Prevalence of Sexual Addiction in Incarcerated Sexual Offenders and Matched Community Nonoffenders. Sexual Addiction and Compulsivity, 15.

Muldner-Nieckowski, Ł. (2015). Różne oblicza seksoholizmu. Rozpoczynanie terapii osób pochłoniętych nadmierną aktywnością seksualną. Świat Problemów, 3.

Nowosielski, K. (2010). Cyberseksualność. In Z. Lew-Starowicz \& V. Skrzypulec (Eds.). Podstawy seksuologii. Warszawa: Wydawnictwo Lekarskie PZWL.

Penix Sbraga, T., O'Donohue, W. (2003). Jak pokonać uzależnienie od seksu? Trening. Gliwice: Wydawnictwo Helion.

Pozdal, M. (2008). Cyberseks - nowe możliwości i zagrożenia. In A. Jodko (Ed.). Tabu seksuologii. Warszawa: Wydawnictwo Academica.

Reber, A.S., \& Reber, E.S. (2008). Słownik psychologii. Warszawa: Wydawnictwo Naukowe Scholar.

Rosenberg, K. P., Carnes, P., \& O’Connor, S. (2014). Evaluation and Treatment of Sex Addiction. Journal of Sex \& Marital Therapy, 4o(2).

Rowicka, M. (2015). Uzależnienia behawioralne. Profilaktyka i terapia. Warszawa: Fundacja Praesterno.

Ryan, T. (2014). Już się nie wstydzę. Wyznania mężczyzny uzależnionego od seksu. Poznań: Wydawnictwo W Drodze.

Smaś-Myszczyszyn, M. (2014). Miejsce wstydu w terapii osób uzależnionych od seksu. Świat Problemów, 4.

Willingham, R. (2014). Uwolnij się! Uzależnienie seksualne i uzdrawiająca moc Jezusa. Kraków: Wydawnictwo Esprit. 
Woźniak, K. (2012). Seks i seksualność w dobie ponowoczesności. Opole: Wydawnictwo Naukowe Scriptorium.

Zabielska, J. (2009). Edukacja seksualna w szkole - wstydliwy problem. In M. Kaczorek,

K. Stachura (Eds.). Przemiany seksualności. Gdańsk: Wydawnictwo Uniwersytetu Gdańskiego.

Zapf, J., Greiner, J., \& Carroll, J. (2008). Attachment Styles and Male Sex Addiction. Sexual Addiction \& Compulsivity, 15.

Zdrada, D. (2017). Seksoholizm - perwersja i miłość. Warszawa: Wydawnictwo Difin. Zwoliński, A. (2014). Cyberseks. Kraków: Wydawnictwo Petrus.

\section{UZALEŻNIENIE OD SEKSU: TERMINOLOGIA, ETIOLOGIA, FENOMENOLOGIA I DIAGNOSTYKA}

Streszczenie: $\mathrm{W}$ artykule przeanalizowano $\mathrm{w}$ oparciu o podejście interdyscyplinarne wybrane aspekty zjawiska seksoholizmu jako przejawu uzależnienia behawioralnego. Podkreślono przy tym rolę zmysłowości i selektywności w życiu seksualnym. Autorka położyła główny nacisk na problemy definicyjno-terminologiczne i kwestię identyfikacji specyficznych cech uzależnienia od seksu. Ponadto odtworzyła historyczne i diagnostyczne pytania związane $z$ badaniem omawianego zjawiska. W szczególności prześledziła zespoły przyczyn mających wpływ na powstanie uzależnienia od seksu, takie jak: somatyczne, psychiczne, społeczne, sytuacyjne.

Słowa kluczowe: seks; uzależnienie; seksoholizm; erotomania; przyczyny; diagnoza.

Iryna Kurlak - profesor zwyczajna, doktor habilitowana, zatrudniona w Katedrze Resocjalizacji i Profilaktyki Społecznej Uniwersytetu Kardynała Stefana Wyszyńskiego, autorka ponad 160 prac naukowych, w tym czterech monografii, m.in.: Podstawy pedagogiki opiekuńczej (Lwów 2015; w języku ukraińskim), Pedagogika postpenitencjarna: zasady teoretyczne i realia praktycznego zastosowania w Polsce (Lwów 2010; w języku ukraińskim). Adres korespondencyjny: Wydział Nauk Pedagogicznych, ul. Wóycickiego 1/3, 01-938 Warszawa. Adres e-mailowy: i.kurlak@uksw.edu.pl. 